\title{
Larvicidal and Synergic Effects of two Biopesticides (Azadirachta indica and Metarhizium anisopliae) against Larvae of Culex quinquefasciatus (Diptera, Culicidae) (Say, 1823)
}

\author{
Thierno Seydou BADIANE¹ , Raymond Demba NDIONE1, \\ Mamour TOURE1, Fawrou SEYE2, Mady Ndiaye ${ }^{1}$
}

\begin{abstract}
${ }^{1}$ Cheikh Anta Diop University of Dakar, Faculty of Sciences and Technology, Department of Animal Biology, Laboratory Biology of Reproduction (L.B.R.), Unit of Entomology, BP 5005 Dakar Fann (Senegal)

${ }^{2}$ UFR Health Sciences de la Santé, University Gaston Berger of Saint Louis
\end{abstract}

\begin{abstract}
Mosquitoes in general and Culex quinquefasciatus in particular have for a long time constituted a source of nuisance due to the diseases they transmit, stings and annoying buzzing. They are also a public health problem. This is why this study is aimed at finding a biopesticide that can fight effectively but also be an alternative to chemical residual pesticides in the environment. Concentrations of biopesticides used are ranged from $2.510^{8}$ to $12.510^{8}$ spores $/ \mathrm{ml}$ with intervals of $2.510^{8}$ spores $/ \mathrm{ml}$ for Metarhizium anisopliae. Concentrations ranging beetween $810^{-4} \mathrm{~g} / \mathrm{ml}$ to $4010^{-4} \mathrm{~g} / \mathrm{ml}$ with intervals of $810^{-4} \mathrm{~g} / \mathrm{ml}$ of Azadirachta indica (Suneem 1\%) were used to fight against 100 three instars larvae of Culex quinquefasciatus. Concentrations of the mixture of Azadirachta indica (Sunnem 1\%) and Metharhium anisopliae ranging from $0.02 \mathrm{ml}+210^{8}$ spores $/ \mathrm{ml}$ to $0.02 \mathrm{ml}+110^{8}$ spores $/ \mathrm{ml}$ were used to study synergic effects of these two biopesticides. One hundred (100) of three instars larvae of Culex quinquefasciatus are used as control and placed in the same jars with $500 \mathrm{ml}$ of distilled water. Metarhizium anisopliae (green muscle) have caused 50\% mortality of three instars larvae of Culex quinquefasciatus after 3 days. Azadirachia indica (Suneem 1\%) have gaved a mortality more than $60 \%$ after 2 days. The mixture Azadirachta indica (Suneem $1 \%$ ) and Metarhizuim anisopliae caused a high mortality with a rate that exceeds $90 \%$ in 3 days. The mixture also prevented a larval moult thus stopping their growth and development. In summary, both Metharizium anisopliae and Azadirachta indica (Suneem 1\%) are effective against three instars larvae of Culex quinquefasciatus. Their mixture caused a synergic effect and thus increased their individual efficacy of two biopesticides.
\end{abstract}

Keywords: Azadirachta indica, Metarhizium anisopliae, Culex quinquefasciatus, mortality, efficacity

\section{Introduction}

In Senegal and around the world, mosquitoes have always been considered a source of nuisance for humans, mainly because they can be vectors of disease. In fight against mosquitoes that cause many buzzing, sting and diseases such as yellow and dengue fevers and malaria, various methods based on chemicals products are adopted. These chemicals methods are most frequent to fight pests (RegnaultRoger and Hamraoui, 1997). However, due to their undesirable effects on environment and human health, the use of pesticides has been widely criticized in recent years (Lorito et al., 1994). In response to the emergence of resistant species, some west african researchers studied double impregnation of mosquito net with two chemicals products (pyrethroid and carbamate). The efficacy of this association was also demonstrated in a field trial in Côte d'Ivoire against mosquitoes of the genus Anopheles and Culex resistant to pyrethroids (Masson, 2003). This mixture involves a synergistic effect between these two insecticides, which gives it an advantage in control of mosquitoes. Thus, there is reduction of doses to be applied and better efficiency. Mixtures of chemical insecticides may be an effective strategy for resistance management, but are harmful to non-targets.

To develop alternatives for chemical methods, researchers now turn to biological insecticides such as neem (Azadirachta indica A. Juss) and fungi (Aspergillus clavatus and Metarhizium anisopliae).

This article is published under the terms of the Creative Commons Attribution License 4.0

Author(s) retain the copyright of this article. Publication rights with Alkhaer Publications.

Published at: http://www.ijsciences.com/pub/issue/2017-04/

DOI: 10.18483/ijSci.1258; Online ISSN: 2305-3925; Print ISSN: 2410-4477 
Taken separately or in mixture, these biological insecticides have shown better efficacy on mosquito larvae. Thus, the present study concerns a synergic effect between Suneem 1\% (Azadirachta indica) and an entomopathogenic fungus (Metarhizium Anisopliae) on larvae of Culex quinquefasciatus. We have to show:

- larvicidal effects of Suneem $1 \%$ on three mosquito larvae, in particular of Culex quinquefasciatus;

- larvicidal effects of the entomopathogenic fungus Metarhizium anisopliae on the same mosquito larvae; - compatibility between Suneem $1 \%$ and the fungus Metarhizium anisopliae;

- synergic effects between the Suneem1\% (Azadirachta indica) and the entomopathogenic fungus (Metarhizium anisopliae).

\section{II- MATERIALS AND METHODS}

1- MATERIAL

\subsection{Biological material}

\section{- Suneem 1\%}

Azadirachia indica (Suneem 1\%) was supplied by Senchim a Senegalese chemical industry (Dakar West Africa, Senegal). Suneem $1 \%$ is biochemical product or biopesticides wich poison mosquitoes. It has larvicidal, adulticidal and anti-baiting properties in biological control.

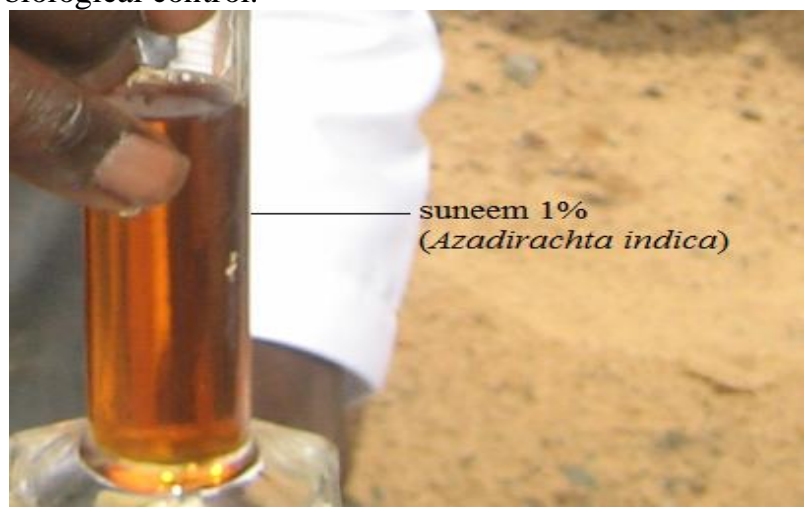

Figure 1: Biopesticide based on Suneem $1 \%$

\section{- Metarhizium anisopliae}

It was synthesized supplied under the "green muscle label" by the Plant Protection Division (DPV) in Dakar, Senegal. Lyophylized spores form of strains were stored in bags according to laboratory conditions. Subsequently these strains were multiplied.

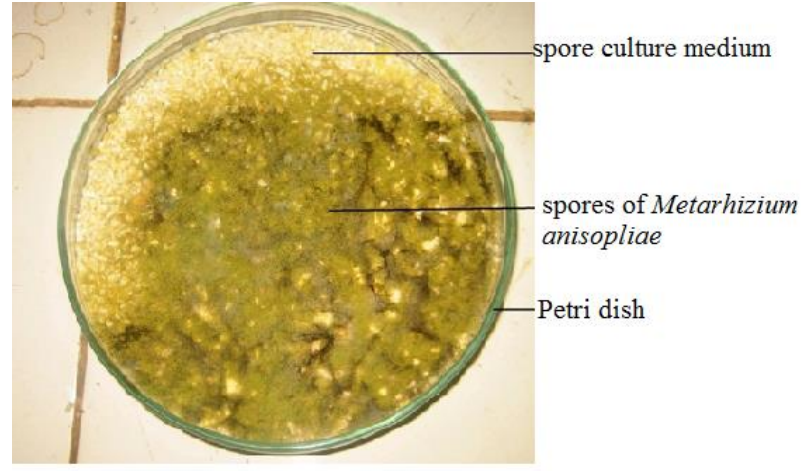

Figure 2: spores of

\section{Metarhizium anisopliae}

\subsection{Animal material}

The larvae mosquitoes of Culex quinquefasciatus were sampled in breeding sites located in suburbs of Dakar (Senegal,west Africa). Larvae were reared in wooden cages measuring $50 \times 50 \times 50 \mathrm{~cm}$ and under laboratory conditions $\left(30^{\circ} \mathrm{C}, 52 \%\right.$ relative humidity and day / night photoperiodicity of approximately 13/11 hours). These larvae are fed with bread powder.

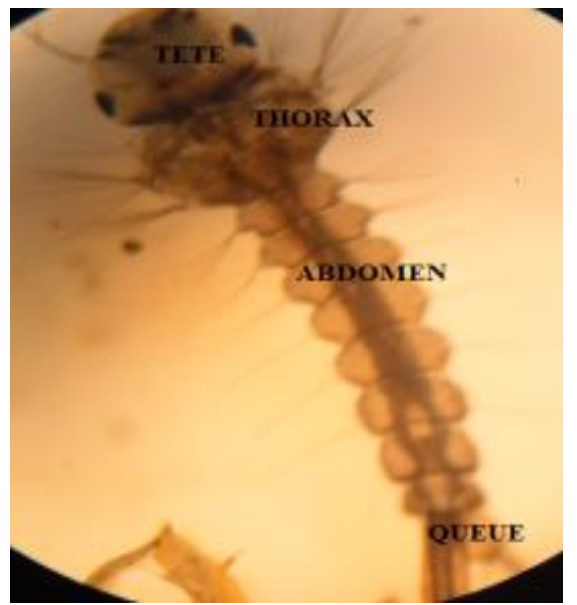

Figure 3: Three instar larvae of mosquito : Culex quinquefasciatus

\section{2- METHODS}

\section{1- Breeding sites surveyed}

This study involved a sample of 16 breeding sites (ponds, marshes, valleys) selected according to different criteria : presence of mosquito larvae in a shelter, accessibility, perenniality and non-treatment with insecticides. Two types were used: positive sites without vegetation and positive ones with vegetation. 


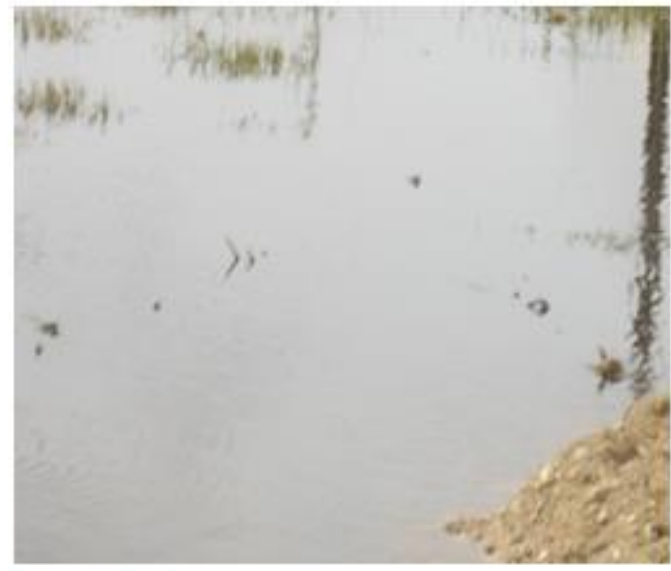

Figure 4: Breeding site without vegetation

\section{2- Sampling Technique}

Sampling of Culex quinquefasciatus larvae is done using the ladle method with a capacity of 500 milliliters. This technique consists of plunging the ladle into water and moving it with uniform movement while avoiding eddies.

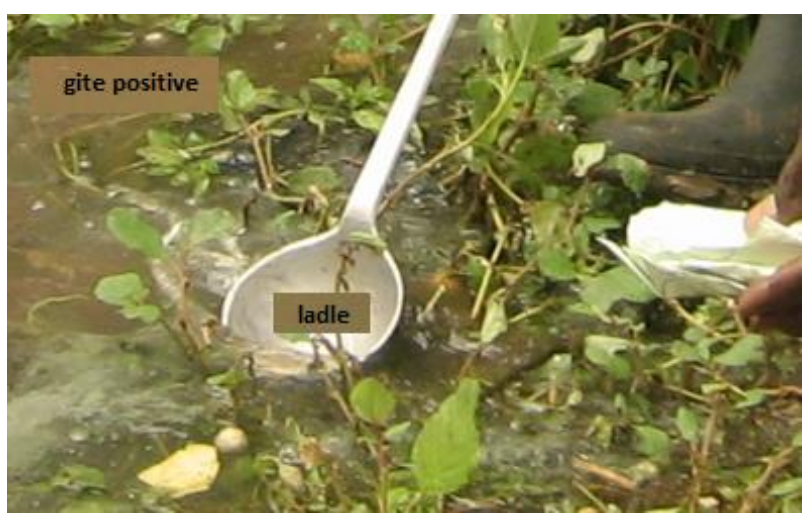

Figure 6: Sampling method of Culex quinquefasciatus larvae by ladle

\section{3 - Culex quinquefasciatus larvae treatment 2.3.1 - With Suneem1\%}

Culex quinquefasciatus larvae were treated directly in breeding sites. These latter were measured by a decameter to determine their extent. Volumes of water were obtained by calculation from these results. Larval densities before treatment are taken by ladle

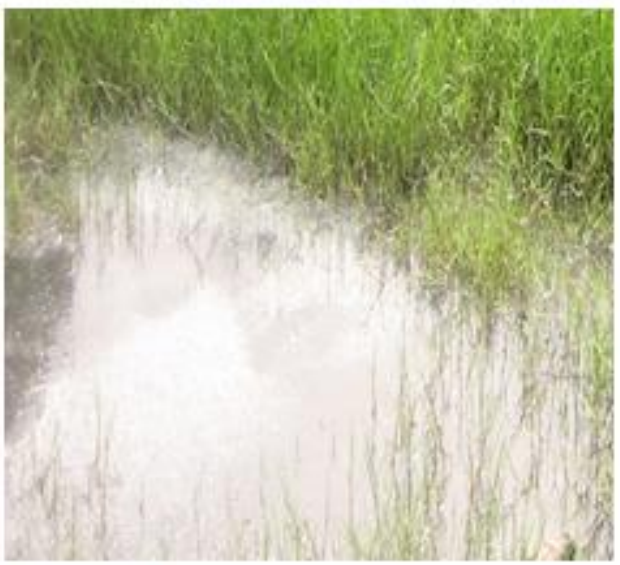

Figure 5: Breeding site with vegetation

method. Three shots of ladle of a volume of about $500 \mathrm{ml}$ each made it possible to count the number of larvae and then to calculate the average densities for each breeding site. Thereafter, the breeding sites are treated with amounts of 25, 30, 35 and $40 \mathrm{ml}$.

\subsection{2- With Metarhizium anisopliae}

The larvae of Culex quinquefasciatus are treated directly in the breeding sites. After indicate water volumes of sites and larval densities before treatment by ladle method, larvae are treated with spores of Metarhizium anisopliae. Thus, amounts of 10 and $12.5 \mathrm{mg}$ are applied in different breeding sites.

\subsection{3 with mixture (Metarhizium anisopliae and Suneem 1\%)}

Larvae of Culex quinquefasciatus are treated directly in deposits with mixture of $50 \mathrm{ml}$ of Suneem $1 \%$ and $10 \mathrm{mg}$ of spores of Metarhizium anisopliae.

\section{III-RESULTS}

The results obtained are analyzed using the statistical software Rogui (R).

\section{1- Larval densities with Suneem 1\%}

The results of treatment with Azadirachia indica (Suneem 1\%) are presented in form of larval densities recorded in Table 


\begin{tabular}{lccccccccccc}
\hline $\begin{array}{l}\text { Gites } \\
\text { Products }\end{array}$ & Parameters & KMF & MB & PKR10 & KM U3 & PGR & DTK & TDS & YS & KF & G \\
& & & & & & & & & & \\
\hline & DLAvT & 134 & 99 & 98 & 154 & 109 & 96 & 75 & 95 & 89 & 89 \\
\cline { 2 - 11 } $\begin{array}{l}\text { Suneem } \\
\mathbf{1 \%}\end{array}$ & DLApT & 47 & 32 & 35 & 46 & 37 & 34 & 28 & 35 & 36 & 29 \\
\cline { 2 - 11 } & TM & 65 & 68 & 64 & 70 & 66 & 65 & 62 & 63 & 60 & 67
\end{tabular}

Table 1: Front larval densities and after treatment with Azadirachia indica (Suneem 1\%).

Legend: KFM: Keur Mbaye Fall, MB: Mbao Baobab, PKR10: Pikine Street 10, KM U3: Keur Massar U3, PGR: Pikine Guinaw Rail, DTK: "Djiddah Thiaroye Kaw", TDS: "Thiaroye Darou Salam", YS: "Yembeul Sud", KF: "Kaffrine", G: "Goudiry", DLAvT: Larval densities before treatment, DLApT: Larval densities after treatment, TM : Mortality rates.
Larval densities of Culex quinquefasciatus decrease after treatment with Azadirachia indica (Suneem $1 \%$ ). Average mortality rate which around $70 \%$ and higher.

Table 2: Larval densities before and after treatment with Metarhizium anisopliae

\begin{tabular}{|c|c|c|c|c|c|c|c|c|c|c|c|}
\hline $\begin{array}{c}\text { Gites } \\
\text { Products }\end{array}$ & Parameters & KMF & MB & PKR10 & $\begin{array}{c}\mathbf{K M} \\
\mathbf{U 3}\end{array}$ & PGR & DTK & TDS & YS & $\mathbf{K F}$ & G \\
\hline \multirow{3}{*}{$\begin{array}{c}\text { Metarhizium } \\
\text { anisopliae }\end{array}$} & DLAvT & 107 & 82 & 90 & 141 & 87 & 92 & 69 & 84 & 85 & 92 \\
\hline & DLApT & 44 & 38 & 38 & 62 & 35 & 36 & 31 & 35 & 37 & 40 \\
\hline & TM & 59 & 54 & 58 & 56 & 60 & 61 & 55 & 58 & 56 & 56 \\
\hline
\end{tabular}

Legend: KMF: "Keur Mbaye Fall", MB: "Mbao Baobab", PKR10: "Pikine Street 10", KM U3: "Keur Massar U3", PGR: "Pikine Guinaw Rail", DTK: "Djiddah Thiaroye Kaw" TDS: "Thiaroye Darou Salam", YS: "Yembeul Sud", KF: "Kaffrine", G: "Goudiry", DLAvT: Larval densities before treatment, DLApT: Larval densities after treatment, TM: Mortality rates.

These results show a decrease in larval densities of Culex quinquefasciatus after treatment with
Metarhizium anisopliae. This reduction is close to $50 \%$ mortality. In natural environment, Metarhizium anisopliae is effective against Culex quinquefasciatus larvae.

3- Larval densities with mixture (Azadirachia indica (Suneem 1\%) and Metarhizium anisopliae)

The results of treatment with mixture (Azadirachia indica (Suneem 1\%) and Metarhizium anisopliae) are presented in the form of larval densities recorded in Table 3 .

Table 3: Larval densities before and after treatment with mixture (Azadirachia indica (Suneem 1\%) and Metarhizium anisopliae

\begin{tabular}{cccccccccccc}
\hline \multirow{2}{*}{$\begin{array}{c}\text { Gites } \\
\text { Products }\end{array}$} & Parameters & KMF & MB & PKR10 & $\begin{array}{c}\text { KM } \\
\text { U3 }\end{array}$ & PGR & DTK & TDS & YS & KF & G \\
\hline \multirow{2}{*}{ Melange } & DLAvT & 164 & 103 & 115 & 162 & 113 & 109 & 98 & 112 & 107 & 98 \\
\cline { 2 - 10 } & DLApT & 11 & 08 & 06 & 08 & 09 & 05 & 03 & 06 & 06 & 03 \\
\cline { 2 - 10 } & TM & 93 & 92 & 95 & 95 & 92 & 95 & 97 & 95 & 94 & 97
\end{tabular}


Legend : KFM: "Keur Mbaye Fall", MB: "Mbao Baobab", PKR10: "Pikine Street 10", KM U3: "Keur Massar U3", PGR: "Pikine Guinaw Rail", DTK: "Djiddah Thiaroye Kaw" TDS: "Thiaroye Darou Salam", YS: "Yembeul Sud", KF: "Kaffrine", G: "Goudiry", DLAvT: Larval densities before treatment, DLApT: Larval densities after treatment, TM: Mortality rates.

These results show that larvae of Culex quinquefasciatus underwent heavy mortalities following treatment with mixture (Azadirachia indica (Suneem 1\%) and Metarhizium anisopliae). These mortalities revolve around $95 \%$. Therefore mixture (Azadirachia indica (Suneem 1\%) and Metarhizium anisopliae) is effective against the larvae of Culex quinquefasciatus.

\section{4- Comparison of larval densities for the two biopesticides used (Azadirachia indica (Suneem 1\%) , Metarhizium anisopliae) and their mixture}

The evolution of these larval densities as a function of the two biopesticides taken separately and their mixture is presented in diagram. 7 corresponding to pads:
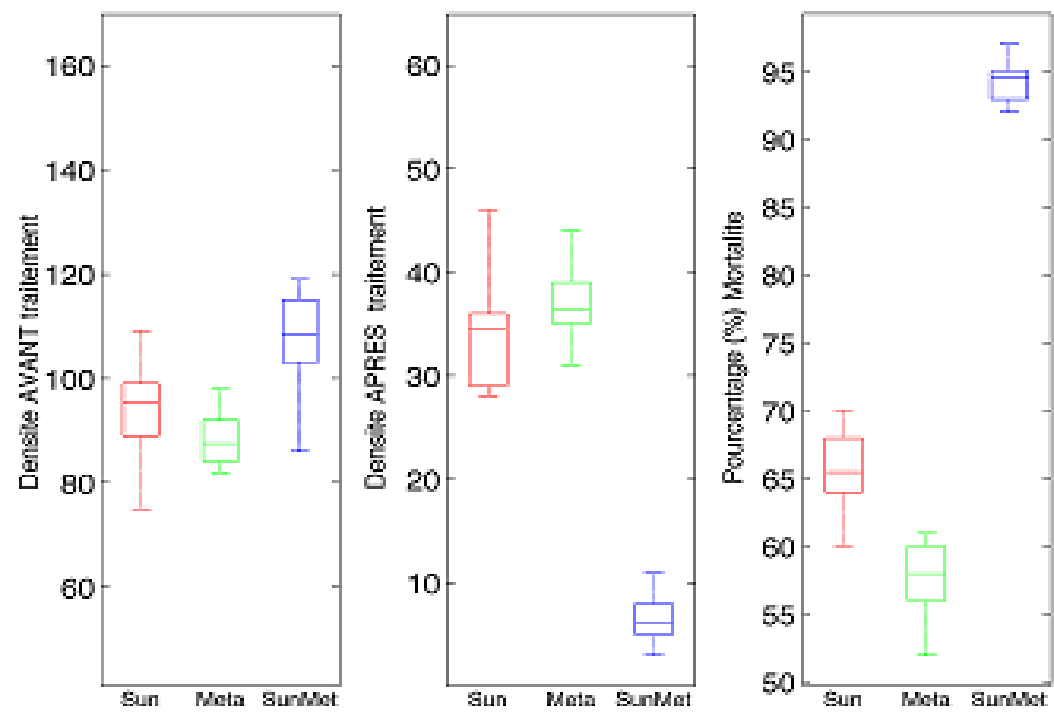

Figure 7: Comparative larval densities of the three biopesticides used (Suneem1\%, Metarhizium anisopliae and the mixture (Azadirachia indica (Suneem 1\%) and Metarhizium anisopliae). Legend : Sun: "Suneem1\%"; Meta: "Metarhizium anisopliae"; SunMeta: "Suneem + Metarhizium anisopliae"

It is found that the larval densities after treatment for each biopesticid are much lower than densities of the mixture. The mortality rates are very strong for the mixture, followed by Azadirachia indica (Suneem $1 \%$ ) and Metarhizium anisopliae. Ultimately, the mixture appears to be much more effective than Suneem $1 \%$ and Metarhizium anisopliae.

\section{IV- DISCUSSION}

The use of natural products such as Azadirachia indica (Suneem 1\%), Metarhizuim anisopliae and the mixture of the two biopesticides in the control of mosquito larvae in general and those of Culex quinquefasciatus in particular is more than current. In Australia, Rae (2004) carried out treatments on larvae of Chortoicetes terminifera (the locusts of Australia) with Green Guard $®$, formulated from a strain of Metarhizuim anisopliae.

Results on the application of Azadirachia indica (Suneem 1\%) to larvae of Culex quinquefasciatus confirm the work of Attri and Prasad (1980) which showed the efficacy of neem oil on Culicidae larvae and Scott and Kaushik (2000) on the efficacy of Margosan-O® on Culex quinquefasciatus, those of Sèye et al. (2004) with formulated neem oil (LD50 at $3 \mathrm{mg} / \mathrm{l}$ in 48 hours) and those of Ndione et al. (2007). Lepage et al., (1992) used several strains of entomopathogenic fungi (Metarhizium anisopliae, Cordyceps militaris and Tolypocladium cylindrosporum) to control a few biting diptera. They concluded that all the strains tested, Metarhizium anisopliae, seem to be the most interesting for the 
biological control of larvae of biting Diptera. SaintLouis et al., (2001) confirmed that Metarhizium anisopliae is a promoter fungus for biological control due to its efficacy at all stages of an insect development and could be an excellent candidate as an alternative measure to synthetic pesticides In the context of biological control or integrated pest management. These results are similar to those obtained by Alves et al. (2002), which recorded an early mortality of larvae of Culex quinquefasciatus treated with Metarhizium anisopliae from the first day of treatment.

The work of Ravallec et al. (2003) demonstrated that Metarhizium anisopliae had a distinct effect on Aedes albopictus larvae. These results for the applications of an entomopathogenic fungus such as Metarhizium anisopliae on insect larvae confirm the Work of Toure (2006) which showed that the spores of Metarhizium anisopliae caused the mortality of the Senegalese locust with a LD50 of 4 days and a TL100 of 7 days for a dose of $4.3 .10^{7}$ spores / $\mathrm{ml}$. Our study fits right Line with these various published articles. Indeed, the results of our study allowed us to note a considerable decrease in the range of $50 \%$, $70 \%$ and $95 \%$ respectively for treatments with Metharhizium anisopliae, Azadirachta indica (Suneem1\%) and the mixture of both. These results confirm and even complement the work of the authors cited above. The adoption of this innovative method of mixing effective biopesticides, thus creating a synergistic effect in the control of the larvae of Culex quinquefasciatus, has several advantages in particular resulting in a decrease in mosquito larvae on the one hand and related diseases and other diseases preserve an already fragile ecosystem. Indeed, our natural treatments showed average values of temperature, $\mathrm{PH}$ and relative humidity respectively of the order of $30^{\circ} \mathrm{C}, 10$ and $60 \%$. The work of Blanford \& Klass (2004) Concluded that temperatures below $38^{\circ} \mathrm{C}$ during the day and above $20^{\circ} \mathrm{C}$ overnight are considered favorable in the control of mosquitoes.

In addition to the stimulating factor that is the physicochemical conditions of natural deposits, the time factor or duration of treatment appears to be determinant in the results. The residence of the larvae in the treated zone for at least 48 hours, gives a better efficiency to the treatment. Mortality and sporulation after $6 \mathrm{~h}$ and $24 \mathrm{~h}$ of exposure are lower than those after $48 \mathrm{~h}$.

\section{Conclusion}

In sumary, it seems relevant to remember that Azadirachta indica (Suneem 1\%) and Metarhizium anisopliae are very effective against larvae of Culex quinqueafasciatus in particular, and against mosquito larvae in general. But this efficacy appears much more important when these two biopesticides are mixed. In perspective it opens up to the scientific community a use of the entomopathogens (bacteria or fungi), of deregulators of growth in a much more effective biological control.

\section{References}

I. ABBOT, W.S. (1925)-A method of computing the effectiveness of an insecticide. J. Econ. Entomol. 18:265-267.

II. AGUDA and al., (1996) and Gonzalez and al., (1996) verified the negative effect of neem on metarhizuim on germination

III. Aguda RM. Rombach MC. and Shepard BM. 1986. Effect of "neem" oil on germination and sporulation of the entomogenous fungus Metarhizium anisopliae. Int. Rice Res. Newsletter; 11:34-35.

IV. ALIERO, B.L. (2003)- Larvicidal effects of aqueous extracts of Azadirachta indica (neem) on the larvae of Anopheles mosquito. African journal of Biotechnology Vol.2 (9) : 325-327, September 2003.

V. ALVES and al., (2000) on methods for calculating compatibility between neem oil and Metarhizium.

VI. Alves(2002) Potential of some Metarhizium anisopliae isolates for control of Culex quinquefasciatus (Dipt.Culidae).J.of appl.Ent, 126: 504-509.

VII. ATTRI B.S \& PRASAD G.R. (1980)- Neem oil extractive an effective mosquito larvicide. Indian $\mathrm{J}$. Entomol. $42:$ 371-374.

VIII. DANIS M \& MOUCHET J. (1991) - Malaria, Marketing Edition / Ellipses, 1991 I.S.N. 0993; 3948, No. L 37094, 240p.

IX. DARRIET F. (1998) - The fight against harmful mosquitoes and vectors of diseases. The development of new insecticides for use against mosquitoes in tropical Africa. Edition Kartala ISBN: 120p

X. DE BARJAC H., SUTHERLAND D.J. (1990)Bacterial control of mosquitoes and blackflies: chemistry, genetic and applications of Bacillus thuringiensis israelensis and Bacillus sphaericus. New Brunswick, NJ, Rutgers university press

XI. Driver et al. (2000): effect of "neem" oil on germination and sporulation of the entomogenous fungus Metarhizium anisopliae

XII. ESSAID A., (1991). The locust fight edition, John Libbery Eurotext. Bristsh Library cataloging in publication data AUPELF / UREF: 306p

XIII. Goettel M.S. (1992). Fungi as biological control agents. Biological control of locusts under the direction of C.J. Lomer and C. Prior p.122-131. Ibadan, Nigeria: CAB International / IITA.

XIV. Goettel M.S., St Leger R.J., Rizzo N.W., Staples R.C et Roberts D.W. (1989). Ultrastructural localization of a cuticle-degrading protease produced by the entomopathogenic fungus Metarhizium anisopliae during penetration of host (Manduca sexta) cuticle. $J$. General. Microbiol. 135 :2233-2239.

XV. Gonzalez, D. M. E.; Valbuena, P. B. F.; Rivera, M. A.; Bustillo, P. A. E. and Chaves, B. (1996), Viabilidad del hongo Metarhizium anisopliae en mezcla con agroquimicos, Rev. Quintela et al (1997a) Colomb. de Entomol., 22, 31-36.

XVI. HIROSE and al. (2001) which showed $36 \%$ inhibition with neem oil with fungus 
XVII. Ibrahim L., Butt T.M., Beckett A et Clark S.J. (1999). The germination of oilformulated conidia of the insect pathogen Metarhizium anisopliae. Mycol. Res. 103:901907.

XVIII. Jenkins N.E., Heviefo G., Langewald J., Cherry A.J et Lomer C.J. (1998).

XIX. Kaijiang L et Roberts D.W. (1986). The production of destruxins by the entomogenous fungus Metarhizium anisopliae var major. J. Invertebr. Pathol. $47: 120-122$.

XX. KANDJI T. (1996) - Optimization of the use of neem (Azadirachta indica A. Juss) in the protection of the seeds of three forest legumes against species of the genus Caryedon (coleopterae bruchidae). Engineer's thesis Agronomist, ENSA, Thies, 46p.

XXI. KARCH S. \& COZ J. (1983) - Histopathology of Culex pipiens Linne (diptera: culidae) subjected to the larvicidal activity of Bacillus sphaericus 1593-4. Cah. ORSTOM, (Ser., Entom Med and Parasitol.) 21: 225230.

XXII. KARCH S. \& COZ J. (1983)- Histopathologie de Culex pipiens Linne (diptera: culidae) soumis a l'activité larvicide de Bacillus sphaericus 1593-4. Cah. ORSTOM, (ser. Entom. Med. Et Parasitol.) $21: 225$ 230.

XXIII. KONAM Y.L., KOFFI A.A., DOANNIO J.M.C. \& DARRIET F. (2003) - Resistance of Culex quinquefasciatus (SAY, 1823) to Deltamethrin and the use of impregnated mosquito nets in Bouake, Côte d'Ivoire. Medical Entomology. 128-129

XXIV. KOUA K.H. (1994) - Demonstration of the larvicidal activity of Persea american on Anopheles gambia s.l. a mosquito of medical importance. Thesis Doctorate 3rd cycle. Univ. Cocody Abidian (Cote d'Ivoire). 123p.

XXV. KOUA K.H. HAN S.H. \& ALMEIDA M.A. (1998) Histopathology of Anopheles gambiae s.l. Giles, 1902 (diptere, culicidae) subjected to the activity of the aqueous extract of Persea americana Miller, 1768 (Lauraceae). Medical Entomology Maniscrit n0 1868.

XXVI. LACEY, Urbina M.J. \& HEIZMAN C.M. (1984)Sustained-release formulations of Bacillus sphaericus and Bacillus thuringiensis (H-14) for control of conterbreeding Culex quinquefasciatus. Mosquito News.

XXVII. Lepage S., Charpentier G., Pecqueur D., Vey A and Quiot J.M. (1992). Use of entomopathogenic fungal toxins in the control of biting Diptera. Same. Soc. Belgian. Ent. 35: 139-143.

XXVIII. Lepage S., Oi-Pentier G., Pecoueur D., Vey A. and Ouiot J.M. (1991). Use of entomopathogenic mushroom toxins in the control of biting Diptera. Proceedings of the Third International Conference of Entomologists of French. Gembloux Belgium. Memoirs of the International Society of the Royal Belgians of Entomology.7p.

XXIX. Masson, 2003 field trial in Côte d'Ivoire against mosquitoes of the genus Anopheles and Culex resistant to pyrethroids.

XXX. Mohamed A.K., Hernandes D et Nelson R.S. (1983). Susceptibility of various instars of Culex quinquefasciatus to two strains Metarhizium anisopliae var.anisopliae. Journ. Flor. Anti- Mosquito. Asso. 54 (1) : 5-8.

XXXI. Mohanty S.S., Raghavendra K., Mittal P.K et Dash A.P. (2008). Efficacy of culture filtrates of Metarhizium anisopliae against larvae of Anopheles stephensi and Culex quinquefasciatus J.Ind.Microbiol.Biotechnol .35 :1199-1202.

XXXII. Ndione and al (2007): Biocontrol of mosquito larvae (Culex quinquefasciatus, Aedes, Aegypti linnaeus, Anopheles gambiae s.l) by neem products (Azadirachta indica, A.JUSS): study of sensitivity and histopathology.

XXXIII. O.M.S. (1963). Methods for determining susceptibility or resistance of mosquito larvae to insecticides. In Resistance to insecticides and vector control. Thirteenth report of the WHO Expert Committee on Insecticides, Geneva: WHO, Ser.Rapp.techn.256, pp. 55-60.

XXXIV. O.M.S. (1970). Insecticide resistance and vector control. Sér.Rapp.Techn.443

XXXV. Quintela ED. and McCoy CW. 1998. Synergistic Effect of Imidacloprid and Two Entomopathogenic Fungi on the Behavior and Survival of Larvae of Diaprepes abbreviatus (Coleoptera: Curculionidae) in Soil. J. Econ. Entomol; 91: 110-122.

XXXVI. Riba G(1986).Comparative studies of Metarhizium anisopliae and Tolypocladium cylindrosporum as pathogens of mosquito larvae.J.Am.Mosq Control.Assoc.,2,p:469-473.

XXXVII. Scholte et al., 2003 a, b: effect of "neem" oil on germination and sporulation of the entomogenous fungus Metarhizium anisopliae

XXXVIII. SCOTT I.M. \& KAUSHIK N.K. (1998)- The toxicity of Margosan-O a product of neem seeds, to selected target and nontarget aquatic invertebrates, Arch Environ Contam. Toxicol., 35:436-431.

XXXIX. SCOTT I.M. \& KAUSHIK N.K. (2000)- The toxicity of a neem insecticide to populations of Culicidae and other Aquatic Invertebrates as in in situ Microcosms Archives of Environnemental Contamination and toxicology, 39, P. 329-336.

XL. SEYE F, NDIONE R. D., NDIAYE M. (2004) Efficacy test of neem products (Azadiracta indica A .JUSS) with Deltamethrin on larvae and nymphs and mosquito (Culex quinquefasciastus): histopathological study

XLI. SEYE F., NDIAYE M., FAYE O ET AFOUTOU J.M. (2012). Evaluation of Entomopathogenic Fungus Metarhizium anisopliae Formulated with Suneem (Neem Oil) against Anopheles gambiae s.l. and Culex quinquefasciatus Adults. Malaria Chemotherapy, Control \& Elimination. 1:1-6.

XLII. THURSTON G., KETTELAE., LUCAROTII C., WEAVER C., HALMES S., (2003) - Entomology and natural products. Canadian Forest Service - Atlantic Forestry Center. Www.ultrateck.net

XLIII. TOURE M., 2006: Use of a biopesticide: Metarhizium anisopliae against desert locust larval stages: Schistocerca gregaria and Senegalese locust: Aedaleus senegalensis: histopathological study. 